\title{
Penanaman nilai-nilai religius dalam pembelajaran PPKn di Madrasah Aliyah Ali Maksum Yogyakarta
}

\author{
Miftakhul Huda, ${ }^{a, 1}$ Syifa Siti Aulia ${ }^{b, 2}$ \\ ${ }^{a}$ Program Studi PPKn, Universitas Ahmad Dahlan, Yogyakarta \\ b Program Studi PPKn, Universitas Ahmad Dahlan, Yogyakarta \\ ${ }^{1}$ miftakhul1400009050@webmail.uad.ac.id, ${ }^{2}$ syifasitiaulia@ppkn.uad.ac.id \\ * korespondensi penulis
}

\begin{abstract}
ABSTRAK
Kenakalan remaja yang akhir-akhir ini meningkat bisa dijadikan sebagai indikator turunnya nilai religius di kalangan remaja. Nilai religius menjadi hal yang sangat penting dalam kehidupan setiap individu dan menjadi sikap hidup yang mengacu pada tatanan hidup yang sesuai dengan aturan dalam agama masingmasing. Kondisi sekarang ini, yang penting untuk melakukan upaya agar nilai religius kembali menguat, salah satunya yaitu upaya pemerintah dapat memperkuat eksistensinya adalah lewat jalur pendidikan, baik formal ataupun non formal. Tujuan penelitian ini adalah untuk mengetahui penanaman nilai religius melalui metode pembelajaran PPKn di MA Ali Maksum Yogyakarta. Metode penelitian yang digunakan berupa penelitian kualitatif dengan pendekatan deskriptif kualitatif. Subjek penelitian adalah guru mata pelajaran PPKn dan siswa. Pengumpulan data dalam penelitian ini menggunakan teknik wawancara, pengamatan (observasi), dan dokumentasi. Metode analisis data menggunakan analisis data model interaktif. Berdasarkan hasil penelitian yang sudah dilakukan, bahwa semua unsur yang terkandung di dalam nilai religius disampaikan oleh guru Pendidikan Pancasila dan Kewarganegaraan di dalam pembelajaran. Secara keseluruhan penyampaian unsur-unsur nilai religius kepada siswa menggunakan cara yang berbeda-beda, terkadang guru mengajak siswa unruk berdiskusi dan tidak jarang pula guru membagi siswa menjadi beberapa kelompok kemudian diberi tugas dan hasilnya dipresentasikan di depan kelas. Hal ini dimaksudkan untuk membuat siswa tidak bosan dalam pembelajaran dan bisa menerima penyampaian dengan baik.
\end{abstract}

Kata kunci: nilai religius, metode pembelajaran ppkn

\begin{abstract}
Juvenile delinquency which has recently increased can be used as an indicator of the decline in religious values among adolescents. Religious value becomes a very important thing in the life of each individual and becomes a life attitude that refers to the life order in accordance with the rules in each religion. The current conditions, which are important to make efforts so that religious values are strengthened again, one of which is the government's efforts to strengthen its existence is through education, both formal and informal. The purpose of this study was to determine the planting of religious values through the PPKn learning method at MA Ali Maksum Yogyakarta. The research method used is in the form of qualitative research with a qualitative descriptive approach. The research subjects were PPKn subject teachers and students. Data collection in this study using interview techniques, observation (observation), and documentation. Data analysis method uses interactive model data analysis. Based on the results of research that has been done, that all elements contained in religious values are conveyed by the teacher of Pancasila and Citizenship Education in learning. Overall the delivery of elements of religious value to students using different methods, sometimes the teacher invites students to discuss and not infrequently also the teacher divides students into several groups then given the task and the results are presented in front of the class. This is intended to make students not bored in learning and can receive delivery well.
\end{abstract}

Keywords: religious value, ppkn learning method

Copyright (02020 Universitas Ahmad Dahlan, All Right Reserved

\section{PENDAHULUAN}

Kenakalan remaja yang akhir-akhir ini meningkat bisa dijadikan sebagai indikator turunnya nilai religius dikalangan remaja. Menurut data dari BNN menyebutkan bahwa pengguna narkoba di Indonesia mencapai 5,1 juta pengguna, dan $40 \%$ dari jumlah tersebut merupakan pelajar dan mahasiswa. Selain itu 
menurut survei yang dilakukan oleh Komisi Perlindungan Anak Indonesia (KPAI) dan Kementerian Kesehatan (Kemenkes) pada Oktober 2013 (Komisi Perlindungan Anak Indonesia, 2013) memaparkan bahwasanya $62,7 \%$ remaja di Indonesia telah melakukan hubungan seks diluar nikah, dan $20 \%$ diantaranya pernah melakukan aborsi. Kenakalan tersebut merupakan salah satu indikasi penurunan kesadaran akan nilai religius dikalangan pelajar. Nilai religius bisa diartikan sebagai sikap dan perilaku yang patuh dalam beribadah terhadap agama yang dianutnya (Machali \& Muhajir, 2011). Selain itu juga, nilai religius selalu mengajarkan tentang bagaimana berinteraksi dengan penganut agama lain, seperti saling menjaga dan toleransi.

Kondisi sekarang ini, yang penting untuk melakukan upaya agar nilai religius kembali menguat, salah satunya yaitu upaya pemerintah dapat memperkuat eksistensinya adalah lewat jalur pendidikan, baik formal ataupun non formal. Akan tetapi, menurut Muhib Abdul Wahab dalam Suara Muhammadiyah (Edisi 24/97, 2012: 52-53), fungsi pendidikan nasional belum terwujud secara efektif dan menggembirakan. Para peserta didik dan mahasiswa masih sering terlibat tawuran, merusak kampus, dan sarana umum lainnya.

Salah satu alternatif yang dapat dilaksanakan dalam melaksanakan pendidikan karakter di sekolah adalah pengoptimalan pembelajaran materi Pendidikan Pancasila dan Kewarganegaraan (PPKn). Peran PPKn sangatlah strategis dalam menumbuhkan karakter siswa dimana di dalamnya mengandung materi tentang delapan belas nilai karakter, salah satunya nilai religius (Anas Salahudin, 2013). Selain pendidikan formal terdapat juga pendidikan non formal, salah satunya yaitu Pondok Pesantren. Menurut Sulaiman Pondok Pesantren adalah lembaga pendidikan tradisional Islam untuk mempelajari, memahami, mendalami, menghayati dan mengamalkan ajaran Islam dengan mengedepankan pentingnya moral keagamaan sebagai pedoman perilaku sehari-hari (Sulaiman, 2017). Pesantren merupakan salah satu lembaga pendidikan yang sudah lama menerapkan pendidikan karakter pada anak didiknya. Tugas pokok pesantren adalah mewujudkan manusia dan masyarakat muslim yang beriman dan bertakwa kepada Allah. Para santri dengan kualitas keislaman, keimanan, keilmuan dan akhlaknya, diharapkan mampu memainkan fungsi dan peran ulama.

MA Ali Maksum Krapyak merupakan salah satu sekolah formal yang berada di dalam lingkungan pesantren di Indonesia dan Yogyakarta pada khususnya. MA Ali Maksum
Krapyak masih dibawah naungan Pondok Pesantren Krapyak lebih tepatnya Yayasan Ali Ma'sum Pondok Pesantren Krapyak Yogyakarta, yang merupakan salah satu Pondok Pesantren tertua yang ada di Indonesia. Selain mengkaji mata pelajaran umum layaknya sekolah formal pada umumnya, di MA Ali Maksum juga terdapat beberapa pelajaran yang tidak disampaikan di sekolah formal pada umumnya seperti mata pelajaran nahwu dan sharaf yang merupakan mata pelajaran yang berguna untuk mempelajari ilmu Bahasa Arab. Selayaknya sekolah pada umumnya MA Ali Maksum juga menerapkan mata pelajaran PPKn sebagai salah satu mata pelajaran wajib. Tujuannya sendiri salah satunya adalah menumbuhkan nilai karakter kepada para siswa selain itu juga untuk menumbuhkan jiwa cinta tanah air sebagaimana yang diamanatkan didalam Undang Undang Sistem Pendidikan Nasional No 20 Tahun 2003. Seluruh siswa dan siswi yang ada di MA Ali Maksum juga merupakan santri di Yayasan Ali Ma'sum Pondok Pesantren Krapyak Yogyakarta.

Mata pelajaran PPKn di sekolah berbasis pesantren menjadi hal yang sangat menarik untuk diteliti, biasanya para kyai ataupun mudaris menanamkan nilai religius dengan pengajian menggunakan kitab ataupun materi yang sudah disiapkan oleh Pondok Pesantren. Selain itu juga pada dasarnya Pondok Pesantren merupakan salah satu lembaga pendidikan non formal yang berkonsentrasi kepada ilmu agama. Dengan kata lain tanpa adanya PPKn pun para santri sudah dididik dengan mengedepankan akhlak sebagai salah satu ciri khas Pondok Pesantren. Peneliti tertarik untuk meneliti bagaimana guru PPKn menggunakan metode pembelajaran PPKn berbasis nilai religius di MA Ali Maksum Krapyak Yogyakarta.

\section{METODE}

Penelitian ini menggunakan pendekatan kualitatif untuk mendeskripsikan suatu fenomena yang terjadi. Fenomena tersebut berupa pembentukan karakter religius pada anak. Jadi di sini penulis mengamati situasi pembelajaran yang ada di MA Ali Maksum Krapyak terutama saat mata pelajaran PPKn berlangsung. Subjek penelitian adalah guru dan siswa, untuk melengkapi hasil yang sesuai dalam penelitian, maka dapat ditentukan bahwa subjek penelitian kali ini adalah guru pengampu mata pelajaran PPKn di MA Ali Maksum Krapyak.

Sedangkan objek dalam penelitian kali ini adalah metode pembelajaran Pendidikan Pancasila dan Kewarganegaraan di MA Ali Maksum Krapyak, terutama dalam hal 
penyampaian nilai religius yang terkandung di dalam mata pelajaran Pendidikan Pancasila dan Kewarganegaraan sebagai salah satu upaya menanamkan dan memupuk nilai religius pada siswa.

Teknik pengumpulan data merupakan langkah yang paling strategis dalam penelitian, karena tujuan utama dari penelitian sendiri adalah mendapatkan data (Sugiyono, 2016). Dalam penelitian ini peneliti menggunakan tiga teknik dalam mengumpulkan data, yaitu: (a) Wawancara (Interview), dalam penelitian ini wawancara yang digunakan peneliti adalah teknik wawancara semi terstruktur. Tujuannya adalah untuk memperkuat jawaban atau informasi mengenai pengembangan mata pelajaran Pendidikan Pancasila dan Kewarganegaraan di MA Ali Maksum Krapyak. (b) Observasi yang dilakukan adalah untuk mengetahui bagaimana pengembangan mata pelajaran PPKn di MA Ali Maksum Krapyak terutama dalam pengembangan nilai religius yang terkandung didalamnya sebagai upaya menanamkan dan memupuk nilai religius pada siswa. (c) Dokumentasi.

Dalam teknik pengumpulan data penulis menggunakan 2 triangulasi, yaitu: (a) Triangulasi sumber, untuk menguji kredibilitas data dilakukan dengan cara mengecek data yang telah diperoleh melalui beberapa sumber, peneliti akan mewawancarai beberapa pihak terkait salah satunya yaitu guru mata pelajaran PPKn, wakil kepala sekolah bagian kurikulum dan pengajaran, serta siswa. (b) Triangulasi teknik, digunakan untuk menguji kredibilitas data dilakukan dengan cara mengecek data kepada sumber yang sama dengan teknik yang berbeda. Untuk ini peneliti mengobservasi di dalam kelas dan mengumpulkan dokumen terkait dengan fasilitas dan RPP dari Guru PPKn, wakil kepala sekolah untuk mengecek kesesuaian apa yang telah disampaikan dalam wawancara.

Menurut Sugiyono (2016: 341) pada penelitian kualitatif, penyajian data bisa dilakukan dalam bentuk uraian singkat, bagan, hubungan antar kategori, flowchart dan sejenisnya. Penyajian data dalam penelitian ini mulai dari lokasi penelitian, observasi lapangan sarana prasarana pendukung, serta data-data hasil wawancara.

\section{HASIL DAN PEMBAHASAN}

Penguatan nilai ibadah dalam pembelajaran PPKn di MA Ali Maksum, berdasarkan hasil observasi guru menanamkan nilai ibadah dengan cara menyisipkan materi tentang nilai ibadah di dalam pembelajaran PPKn di kelas. Selain menyampaikan nilai ibadah, guru langsung mengaplikasikan nilai ibadah di kelas, sebelum pembelajaran dimulai guru membimbing seluruh murid untuk mengawali pembelajaran dengan berdoa bersama. Guru menyampaikan nilai ibadah di dalam pembelajaran dengan tujuan untuk membentuk siswa menjadi pribadi yang taat beribadah sebagai wujud syukur atas nikmat yang telah diberikan Allah. Selain itu juga metode penyampaian yang baik menjadikan siswa dapat menerima apa yang telah disampaikan oleh guru. Fasilitas yang memadai juga salah satu faktor pendukung tersampaikannya materi dengan baik. Aplikasi nilai ibadah di dalam pembelajaran dibuktikan dengan diawalinya pembelajaran dengan berdoa secara bersama-sama.

Menanamkan nilai ruhul jihad dalam pembelajaran PPKn di MA Ali Maksum, dengan cara menyisipkan materi tentang nilai ruhul jihad di dalam pembelajaran PPKn di kelas. Di dalam RPP yang dibuat oleh guru tidak ditemukan materi yang secara gamblang menerangkan tentang ruhul jihad. Akan tetapi pada praktiknya guru menyampaikannya dengan menyisipkan di dalam materi pembelajaran PPKn yang disampaikan di kelas.

Guru menyampaikan materi tentang ruhul jihad dengan cara memotivasi siswa supaya tetap bersemangat dalam menuntut ilmu. Tujuan disampaikannya nilai ruhul jihad adalah supaya tumbuh semangat belajar di dalam diri siswa, pantang menyerah dan selalu haus akan ilmu. Sehingga menjadikan mereka pribadi yang kuat dan tidak gampang puas dengan ilmu yang dimilikinya. Penyampaian nilai ruhul jihad ini merupakan sara guru dalam memotivasi siswa agar semangat dalam mencari ilmu dan menjadi pribadi yang kuat. Selain itu juga guru berharap siswa menjadi pribadi yang selalu haus akan ilmu sehingga siswa tidak gampang puas dengan ilmu yang sudah dimiliki.

Menanamkan nilai akhlak dalam pembelajaran PPKn di MA Ali Maksum, dengan cara menyisipkan nilai akhlak di dalam pembelajaran PPKn di kelas. Selain itu guru menyiapkan materi tentang nilai akhlak. Nilai akhlak dianggap penting karena akhlak merupakan faktor penentu cara berperilaku seseorang. Seseorang yang mempunyai akhlak baik akan otomatis berperilaku baik pula. Begitupun sebaliknya, orang yang mempunyai akhlak buruk otomatis perilakunya juga buruk. Ditanamkannya nilai akhlak menjadi salah satu upaya guru menjadikan siswanya menjadi pribadi yang bisa diterima di masyarakat kelak.

Nilai akhlak di dalam pembelajaran PPKn di kelas. Penanaman nilai akhlak dianggap penting karena akhlak merupakan faktor penentu cara 
berperilaku seseorang. Baik buruknya kepribadian seseorang bisa dinilai dari akhlaknya.

Meningkatkan Nilai kedisiplinan dalam pembelajaran PPKn di MA Ali Maksum, dengan cara menyisipkan nilai kedisiplinan di dalam pembelajaran PPKn di kelas. Selain itu guru menyiapkan materi pokok tentang nilai kedisiplinan walaupun tidak dijelaskan secara mendetail. Selain menyampaikan materi untuk menunjang terbentuknya disiplin di diri para siswa guru memberikan contoh langsung, contoh dengan datang tidak terlambat dan memakai seragam dengan rapi.

Walaupun penyampaian nilai disiplin tidak secara mendetail disampaikan akan tetapi murid bisa melihat secara langsung atau mencontoh apa yang dilakukan guru yang nantinya juga akan berkaitan dengan nilai keteladanan. Secara keseluruhan fasilitas penunjang sudah baik dan memadai untuk tersampaikan nya nilai kedisiplinan. Murid pun bisa menangkap pesan yang disampaikan oleh guru dengan baik.

Kesimpulannya guru menyisipkan konten atau materi tentang nilai kedisiplinan ketika pembelajaran PPKn di kelas. Walaupun sifatnya hanya sisipan tetapi murid bisa menangkap pesan yang disampaikan oleh gurunya. Dibuktikan dengan bagaimana mereka berperilaku di dalam kelas saat pembelajaran berlangsung.

Keteladanan lebih kepada memberikan contoh, walaupun tidak jarang juga guru memberikan contoh keteladanan kepada siswa melalui cara menceritakan tokoh-tokoh ataupun pahlawan yang bisa diambil teladannya. Nilai keteladanan sebenarnya bersinergi dengan nilainilai lainnya. Karena percuma seorang guru menjelaskan kepada murid tentang beberapa nilai yang terkandung dalam karakter religius tetapi dirinya sendiri tidak mencerminkan nilai-nilai tersebut. Peserta didik justru akan lebih memperhatikan setiap gerak gerik gurunya dan akan mencontoh apa yang dilakukan gurunya. $\mathrm{Hal}$ ini sejalan dengan apa yang ditemukan di lapangan. Menurut hasil wawancara dengan siswa, siswa menghormati gurunya karena guru tersebut tidak hanya menerangkan tentang nilai keteladanan di kelas akan tetapi juga mengaplikasikan nilai-nilai tersebut di dalam setiap tindak tanduknya.

Kesimpulannya adalah nilai keteladanan memang penting untuk disampaikan, akan tetapi akan lebih baik lagi ketika yang menyampaikannya ataupun guru juga menerapkan nilai-nilai yang disampaikannya di dalam setiap tindak tanduknya. Hal ini sesuai dengan teori yang telah dijabarkan sebelumnya, bahwasanya nilai keteladanan adalah tentang bagaimana murid mencontoh sikap guru bukan hanya berdasarkan tentang materi.

Nilai amanah dan ikhlas dengan cara menyisipkan nilai tersebut di dalam pembelajaran PPKn di kelas. Amanah dan ikhlas merupakan hal yang sejatinya harus dimiliki setiap individu, oleh karena itu harus ditanamkan sejak dini kepada peserta didik. Di dalam teori dikatakan bahwasanya nilai amanah akan menjadikan siswa menjadi pribadi yang jujur dan dapat dipercaya. Sedangkan ikhlas sendiri akan menjadikan siswa menjadi pribadi yang tidak memiliki sifat pamrih atau mengharapkan sesuatu balasan atas apa yang sudah diperbuat.

Mengingat pentingnya nilai tersebut maka penyampaian materi tentang nilai amanah dan ikhlas dianggap perlu. Kesimpulannya adalah tujuan disampaikannya nilai amanah dan ikhlas oleh guru kepada siswa sudah sesuai dengan teori yang telah dijabarkan sebelumnya, yaitu membentuk pribadi yang jujur, dapat dipercaya serta menjadi pribadi yang tidak memiliki sifat pamrih di setiap apa yang sudah peserta didik lakukan.

\section{KESIMPULAN}

Setelah penelitian yang dilakukan di MA Ali Maksum peneliti dapat menyimpulkan bahwasanya semua unsur yang terkandung di dalam nilai religius disampaikan oleh guru Pendidikan Pancasila dan Kewarganegaraan di dalam pembelajaran. Secara keseluruhan penyampaian unsur-unsur nilai religius kepada siswa menggunakan cara yang berbeda-beda, terkadang guru mengajak siswa untuk berdiskusi dan tidak jarang pula guru membagi siswa menjadi beberapa kelompok kemudian diberi tugas dan hasilnya dipresentasikan di depan kelas. Hal ini dimaksudkan untuk membuat siswa tidak bosan dalam pembelajaran dan bisa menerima penyampaian dengan baik. Adapun keenam unsur nilai religius adalah sebagai berikut: (1) Nilai Ibadah, sesuai dengan fakta yang ada, guru menyampaikan nilai ibadah di dalam pembelajaran PPKn. Selain menanamkan nilai ibadah lewat pembelajaran guru juga mempraktikkan secara langsung nilai ibadah tersebut, guru membimbing siswa untuk mengawali dan mengakhiri pembelajaran dengan berdoa. (2) Nilai ruhul jihad, berdasarkan observasi, nilai ruhul jihad ditanamkan oleh guru kepada siswa di dalam pembelajaran PPKn. Adapun maksud ditanamkan nya nilai ruhul jihad supaya siswa memiliki semangat juang dalam menuntut ilmu. Selain itu juga menjadi sarana bagi guru untuk menumbuhkan rasa haus akan 
ilmu supaya siswa tidak gampang berpuas diri dengan ilmu yang didapat. (3) Nilai Akhlak, guru menanamkan nilai akhlak di dalam pembelajaran PPKn di dalam kelas. Penanaman nilai akhlak dirasa penting karena akhlak adalah faktor pembentuk kepribadian seseorang. Baik buruknya perilaku seseorang tergantung dengan akhlaknya. Adapun cara yang menyampaikannya kurang lebih sama dengan nilai lainnya. (4) Nilai Kedisiplinan, guru menyisipkan konten atau materi yang berhubungan dengan nilai disiplin di dalam pembelajaran PPKn. Selain itu guru juga memberikan contoh nilai disiplin kepada siswa melalui perilaku guru. Salah satunya dengan masuk kelas tidak telat dan berpakaian sesuai dengan peraturan yang berlaku di sekolah. Dengan demikian diharap siswa dapat mencontoh apa yang sudah dicontohkan guru PPKn. (5) Nilai Keteladanan, berbeda dengan nilai-nilai lainnya, penyampaian nilai keteladanan lebih kepada memberikan contoh kepada siswa oleh guru PPKn. Walaupun tidak jarang juga guru menceritakan beberapa tokoh-tokoh dengan harapan siswa bisa meneladani setiap kebaikan yang terkandung dalam cerita tersebut. (6) Nilai Amanah dan Ikhlas, guru menyampaikan nilai amanah dan ikhlas di dalam pembelajaran PPKn di dalam kelas. Tujuan disampaikannya nilai amanah dan ikhlas untuk membentuk pribadi yang jujur, dapat dipercaya serta menjadi pribadi yang tidak memiliki pamrih di setiap apa yang dilakukannya.

\section{REFERENCES}

Achmad Ubaedillah, A. R (2012). Pancasila, Demokrasi, HAM dan Masyarakat Madani. Jakarta: Prenadamedia.

Anas Salahudin, I (2013). Pendidikan Karakter. Bandung: Pusaka Setia

Arismantoro. (2008). Tinjauan Berbagai Aspek Character Building Bagaimana Anak Berkarakter. Yogyakrta: PT. Tiara Wacana Yogya.

Asrori, M. (2007). Psikologi Pembelajaran. Bandung: Wacana Prima.

Bawani, I. (1993). Tradisionalisme dalam Tradisi Islam. Surabaya: Al-Ikhlas.

Cendekia, I. (2016, Oktober 6). Islam Cendekia. Diambil kembali dari http://www.google.com/amp/s/www.isla mcendekia.com/amp/2016/10/pengertianmahad-aly-dan-daftar-mahad-aly-diindonesia.html

Dinas Pendidikan Provinsi Jawa Barat. (2018, Juni 3). Dinas Pendidikan Provinsi Jawa Barat.
Diambil kembali dari disdik.jabarprov.go.id/product/7/peraturanmenteri-pendidikan-nasional-nomor-22tahun-2006

Fakhrizal. (2016, November). Jejak Pendidikan. Diambil kembali dari www.jejakpendidikan.com/2016/11/penger tian-dan-macam-macam-nilai.html? $\mathrm{m}=1$

Fathurrohman, M. (2012, 11 2). Kategorisasi Nilai Religius. Diambil kembali dari wordpress: http://www.google.com/amp/s/muhfathur rohman.wordpress.com/2012/11/12/kateg orisasi-nilai-religius/amp/

Hery Noer, A. (1999). Ilmu Pendidikan Islam. Jakarta: Logus.

Humaid. (2018, Juni 22). Pendaftaran Mahasantri Baru Ma'had Aly Krapyak. Diambil kembali dari Pondok Pesantren Krapyak Yayasan Ali Maksum:

https://krapyak.org/2018/06/22/pendaftar an-mahasantri-baru-mahad-aly-krapyak/

John, D. (2016). Pengertia Peserta Didik Menurut Para Ahli. Diambil kembali dari Silabus.Web.Id Informasi Pendidikan dan Kebudayaan: http://www.silabus.web.id/pengertianpeserta-didik/amp/

Komisi Perlindungan Anak Indonesia. (2013). Survey penggunaan narkoba. Jakarta: KPAI.

Lela Camellia Cynthia, T. M. (2016). Pengaruh Fasilitas Belajar dan Motivasi Belajar Terhadap Prestasi Belajar Mata Pelajaran Ekonomi Siswa Kelas XI IPS di SMA Negeri 5 Surakarta Tahun Ajaran 2015/2016. Jurnal UNS.

Machali, I., \& Muhajir. (2011). Pendidikan Karakter "Pengalaman Implementasi Pendidikan Karakter di Sekolah". Yogyakarta: UIN Sunan Kalijaga.

Matondang, Z. (2014). Pembentukan Karakter Santri/wati Berbasis Tradisi Pesantren. Pelangi Pendidikan, Vol.21, No.1, 45-54.

Moeloeng, J. (2014). Metodologi Penelitian Kualitatif. Bandung: Remaja Rosdakarya.

Muiz, M. A. (2017, Agustus 1). Lagi, Kemenag Terbitkan SK 14 Ma'had Aly. Diambil kembali dari Kementerian Agama Republik Indonesia: https://kemenag.go.id/berita/read/505094 /lagi--kemenag,-terbitkan-sk-14-ma---had-aly

Mukhtar. (2013). Metode Penelitian Deskriptif Kualitatif. Jakarta: GP Press Group. 
Mulyana, A. (2018, July 2). Permendikbud Nomor 20 Tahun 2018 Tentang Penguatan Pendidikan Karakter Pada Satuan Pendidikan Formal. Diambil kembali dari Pendidikan Kewarganegaraan: https://ainamulyana.blogspot.com/2018/0 7/permendikbud-nomor-20-tahun2018.html?m=1

Mulyasa, E. (2014). Guru dalam Implementasi Kurikulum 2013. Bandung: PT Remaja Rosdakarya.

Nasution, M. K. (2017). Penggunaan Metode Pembelajaran Dalam Peningkatan Hasil Belajar Siswa. Jurnal Ilmiah Bidang Pendidikan, 9-16.

Noviaturrahmah, F. (2014). Metode Pendidikan Karakter di Pesantren. Pendidikan Agama Islam, vol. XI, No.2, 201-216.

Prasetya, E. (2009). Tiga Hal Pokok Untuk Membangun Akhlak Mulia Anak. Diambil kembali dari Era Muslim: http://www.eramuslim.com/berita/nas.

Putra, H. (2001). Historitas dan Eksistensi Pesantren, Sekolah dan Madrasah. Yogyakarta: PT. Tiara Wacana Yogya.

Ramli, T. (2003). Pendidikan Karakter. Bandung: Angkasa.

Rizka Dwi Seftiana, S. D. (2018). Perencanaan Strategik Pendirian Ma'had Aly Pondok Quran Bandung. Jurnal Manajemen Pendidikan Islam, 173-194.

Samsul Hidayat, M. (2015). Tujuan Pembelajaran Sebagai Komponen Penting dalam Pembelajaran. BPSDMD Provinsi NTB, 1-7.

Sayektiningsih, B. S. (2017). Penanaman NilaiNilai Karakter dalam Pembelajaran Pendidikan Pancasila dan Kewarganegaraan di Madrasah Aliyah Muhammadiyah Klaten. Jurnal Managemen Pendidikan, 228-238.
Sayid Fuad, A.-B. (1975). Asas Al-Nafsiyyah Li Annumuwwi min al Thufulah wa al-Syuyuhah. Kairo: Dar al-Fikr al-'arabi.

Sjarkawi. (2008). Membentuk kepribadian Anak "Peran Moral Intelektual, Emosional dan Sosial Sebagai Eujud Intregitas Membangun Jati Diri". Jakarta: PT. Bumi Angkasa.

Subur, M. (2015). Pembelajaran Nilai Moral Berbasis Kisah. Yogyakarta: Kalmedia.

Sugiyono. (2016). Metode Penelitian Kualitatif. Bandung: CV. Yrama Widya.

Sulaiman, R. (2017). Institusionalisasi Kelembagaan Pendidikan Pesantren. Pendidikan Pondok Pesantren, 149-174.

Suprihatin, S. (2015). Upaya Guru dalam Meningkatkan Motivasi Belajar Siswa. Jurnal Promosi Jurnal Pendidikan Ekonomi UM Metro, 73-82.

Susanti, A. (2017). Model, Metode, Strategi, Teknik Pembelajaran. Diambil kembali dari Academia: www.academia.edu/8959604/Model_Meto de_Strategi_Teknik_Pembelajaran

Syahidin. (1995). Metode Pendidikan Qur'ani Teori dalam Aplikasi. Jakarta: Logus.

Tarigan, E. T. (2017). Menbangun Karakter Bangsa Melalu Pendidikan Kewarganegaraan. Prosding Seminar Nasional Tahunan Fakultas Ilmu Sosial Universitas Negeri Medan, 273-277.

Wahab, M. A. (2012). Suara Muhammadiyah. Yogyakarta: Suara Muhammadiyah.

Winarno. (2014). Pembelajaran Pendidikan Kewarganegaraan. Jakarta: Bumi Aksara.

Yayasan Ali Maksum. (2012). Profil Madrasah Aliyah Ali Maksum Yogyakarta. Yogyakarta: Yayasan Ali Maksum.

Yusran, A. (1997). Dirasah Islamiyah. Jakarta: Raja Grafindo Persada. 